
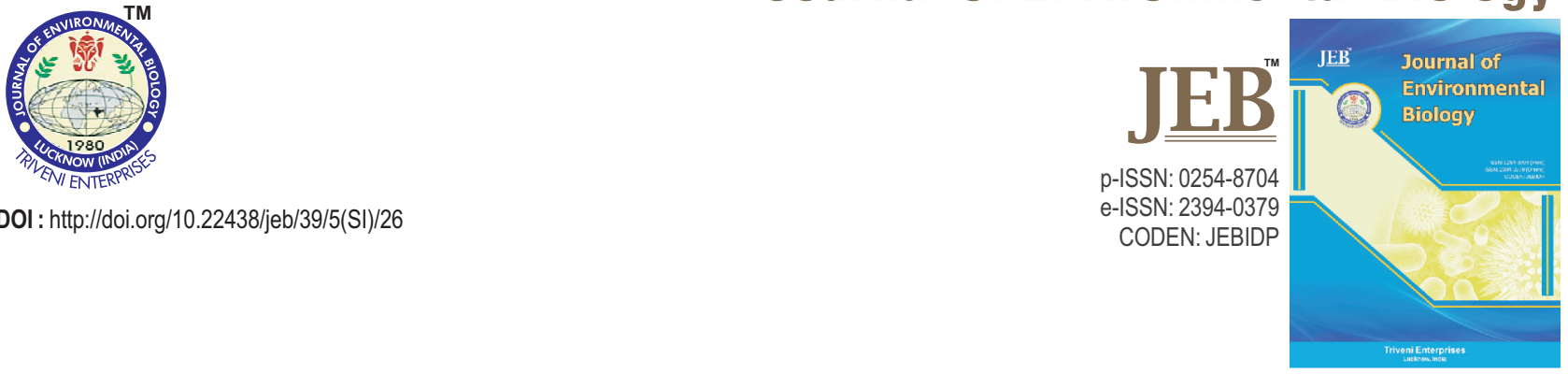

\title{
Phylogeography and population structure of Tenualosa toli inferred from Cytochrome b mitochondrial DNA fragment
}

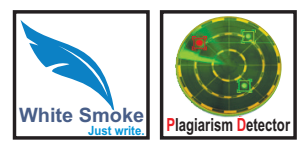

Authors Info

P. Puvanasundram*, Y. B. Esa', K.A.A. Rahim ${ }^{2}$ and S.M. Nurul Amin $^{1}$

${ }^{1}$ Department of Aquaculture, Faculty of Agriculture, Universiti Putra Malaysia, 43400 UPM Serdang, Selangor Darul Ehsan, Malaysia

${ }^{2}$ Faculty of Resource Science and Technology, Universiti Malaysia Sarawak, 94300 Kota Samarahan, Sarawak, Malaysia

${ }^{*}$ Corresponding Author Email : yuzine@upm.edu.my

Key words

Clades

Cyt b sequences

Haplotypes

Phylogenetic structure

Tenualosa toli

Publication Info

Paper received : 16.07.2017

Revised received : 19.09.2017

Re-revised received : 25.11.2017

Accepted : 28.12.2017

\section{Abstract}

Aim : Shad fish of genus Tenualosa subfamily Alosinae (shads) family Clupeidae, are commercially and culturally important estuarine fish in many Asian countries, especially in Sarawak. In this study, the phylogenetics of three species from the genus Tenualosa (Tenualosa toli, Tenualosa macrura and Tenualosa ilisha) was determined.

Methodolgy : Sequence analysis of 910 base pairs of Cytochrome b gene were conducted on the samples of indigenous T.toli $(\mathrm{N}=111)$ and T. macrura $(\mathrm{N}=24)$, which were collected from Sarawak including the samples of non-native T. ilisha $(\mathrm{N}=4)$ obtained from Bangladesh.

Results : A total of 28 haplotypes were found with T. toli producing 15 haplotypes, where 13 haplotypes were unique haplotypes while 2 shared haplotypes among the 6 populations.

Interpretation : Phylogenetic analysis supported the monophyletic status between the three shad species. The highest intraspecific genetic divergences were recorded between imported samples and samples from other localities. There is evidence of overfishing and recently occurred bottleneck events which led to a population size expansion of $T$. toli, especially in Sebuyau, Daro and Mukah.

\section{Collection of Tenualosa toli samples}
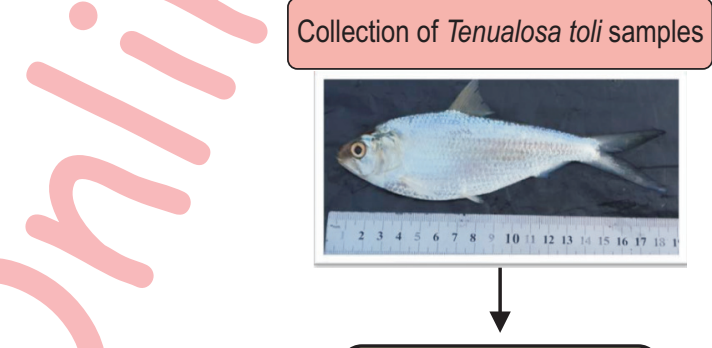

DNA extraction sequence analysis (910 base pairs)

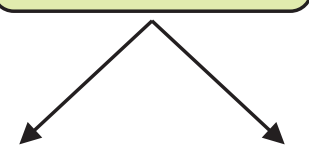

Phylogenetic analysis

- Monophyletic status of T. toli, T. macrura and T. ilisha
DNA polymorphism analysis on $T$. toli

- Exidence of overfishing

- Recently occurred bottleneck

- T. toli population size expansion 


\section{Introduction}

Shad fish of genus Tenualosa subfamily Alosinae (shads) family Clupeidae are commercially and culturally important estuarine fish in many Asian countries, especially in Sarawak. This genus consists of 5 different species worldwide, mainly Tenualosa ilisha, Tenualosa macrura, Tenualosa revesii, Tenualosa thibaudeaui and Tenualosa toli (Blaber et al., 2005). However, only two are found in Malaysia, which are locally known as terubok; T. macrura (sea Terubok) and T. toli (river Terubok), where the distribution of both species are confined along the coastal waters of Sarawak. T. macrura closely resembles $T$. toli but has a smaller head and a longer tail compared with the latter (Blaber et al., 1999). T. toli resembles T. ilisha, which has a longer head (28 to $32 \%$ standard length), shorter caudal fin (25 to $31 \%$ standard length), more gillrakers and spots along the flank (Whitehead, 1985). T. ilisha, also known as Hilsa, is a large anadromous fish that can be found in the coastal area, brackish, estuarine and also fresh water rivers of Bangladesh, India and Myanmar (Whitehead, 1985; Salini et al., 2004). A recent study by Arai and Amalina (2014) established the first record of T. ilisha in Malaysia waters, specifically in Perak River in Peninsula Malaysia. These results suggest that the $T$. ilisha found in Malaysia belongs to a different population from the one found in Bangladesh, India and other countries.

There are 3 core terubok areas in Sarawak mainly Lassa, Saribas and Lupar River as the population of Sarawak river shad (T. toli) can only be found within these three water bodies. T. toli spawns in both the Batang Lupar and Batang Lassa over an extended period, but each female spawns only once (Blaber et al., 1996). This species has long been a prized target by local fishermen for the high price commanded by the roe and the delicious taste of its flesh. The total catch landing for this species has been reported to be depleted to a very low level, due to overexploitation including other subsidiary factors such as environmental degradations and water pollution (Blaber et al., 2005). The current status of $T$. toli within Batang Lupar, Batang Lassa and Batang Saribas, which are known as 'core terubok area' were recorded by Khairul Adha et al. (2014). The smaller terubok (T. toli) also known as 'empirit' are found locally and abundantly in the area, fishery of $T$. macrura occurs at a large scale and local fishermen tend to use smaller mesh size of net (50 $\mathrm{mm}$ to $100 \mathrm{~mm}$ ) for $T$. macrura fishery leading to the increase in 'empirit' fishery as well.

Morphological based identification is a common method applied on adult fishes but this is difficult to apply on juvenile fish. In order to further support morphological identification, the use of different methods for identification is required. The application of molecular markers, mainly DNA markers, are reliable in stock management as well as juvenile fish identification. The genetic diversity data is useful in research related to evolution, conservation and management of natural resources as well as genetic improvement programs (Tanya and Kumar, 2010).
Phylogenetic analysis using DNA characters is one of the best molecular approaches to determine and confirm the systematic and taxonomy status among organisms (Avise, 2000; Esa et al., 2008, 2012; Jeffrine and Esa, 2006). The mitochondrial DNA (mtDNA) has many properties that make it useful for reconstructing phylogenetic history and tracing maternal geologies (Avise, 1994; Stepien and Kocher, 1997). This includes rapid rate of sequence divergence (at least in vertebrates), which allows discrimination of recently diverged lineages, maternal inheritance and absence of recombination. They have also contributed valuable information on population genetic structures, phylogeography and barcoding studies of various fishes (Kamarudin and Esa 2009; Cook et al., 2006; Esa et al., 2000; Esa and Khairul Adha, 2013).

Mitochondrial DNA Cytochrome $b$ (Cyt $b$ ) is an available and universal primer gene, used in many fields to identify species (Hsieh et al., 2001; Irwin et al., 1991; Pääbo and Wilson, 1988). Phylogenetic studies on fish were also conducted using this gene such as the phylogenetic analysis of fishes of the subfamily Schozothoracinae using Cyt b gene (Barat et al., 2012). Cyt b gene is proven in clarifying the status of particular species. For example, Esa et al. (2012) successfully constructed the phylogeny of Malaysian freshwater fishes in the family Cyprinidae inferred from the Cyt b gene.

The taxonomy of clupeiformes has extensively been studied (Whitehead, 1985), but their phylogenetic relationships are still poorly understood. The lack of phylogenetic relationship studies among tropical shads of the genus Tenualosa means that their taxonomic status under the species concept criterion that utilize genetic characters such as the genetic species concept (Baker and Bradley, 2006) have never been tested. Study conducted by Abdul Aziz et al. (2015) on the mitochondrial DNA diversity of Terubok (Tenualosa toli) from Daro and Mukah, Sarawak inferred by partial (Cyt b) concluded that the haplotype and nucleotide diversity was relatively low for both of these populations. In this study, a single haplotype was shared among 76 individuals implying that genetic deprivation occurred due to overfishing.

This study aims to construct phylogenetic tree of genus Tenualosa inferred from sequencing of Cyt b. mitochondrial DNA to examine the systematic and evolutionary relationship among the member of genus Tenualosa. In addition, this study also aims to resolve the population structure among selected population of $T$. toli.

\section{Materials and Methods}

Sample collection : Samples of $T$. toli used in this study were collected from Sebuyau ( $N=25)$, Sadong Jaya $(N=21)$, Satok market $(\mathrm{N}=9)$, Batang Lupar $(\mathrm{N}=20)$, Daro $(\mathrm{N}=12)$ and Mukah $(\mathrm{N}=25)$. Samples of T. macrura were collected from Sadong Jaya $(\mathrm{N}=7)$, Kota Samarahan $(\mathrm{N}=11)$, Daro $(\mathrm{N}=1)$ and Sibu $(\mathrm{N}=5)$. 
Sampling location are shown in Fig. 1. On the other hand, samples of $T$. ilisha $(\mathrm{N}=4)$ were collected from Bangladesh. All samples were identified based on morphological features using key identification of clupeoid species by Whitehead (1985). Tissue and fin samples were collected and preserved in 95\% ethanol and subsequently stored at $-20^{\circ} \mathrm{C}$. Sardinella maderensis sequences, which were used as outgroup taxa, were obtained from Genbank (Accession number: AF472583.1, DQ 19799.1).

DNA extraction, polymerase chain reaction (PCR) and purification of PCR product : Total DNA was extracted using Wizard (B) Genomic DNA Purification system by Promega according to the manufacturer's protocol. The DNA quality and approximate yield were determined by electrophoresis in 1 to $2 \%$ agarose gel $75 \mathrm{~V}$ for $60 \mathrm{~min}$.

A 1140 base pair (bp) segment of Cyt b. gene was amplified with the oligonucleotide primers (5'CGAAGCTTGATATGAAAAACCATCGTTG- 3', forward) and (5'-
AACTGCAGTCATCTCCGGTTTACAAGAC- 3', reverse) (Pääbo, 1990). Approximately, $50-100 \mathrm{ng}$ of template DNA was amplified in a $25 \mu$ reaction mixture which contains $5 X$ buffer, $25 \mathrm{mM} \mathrm{MgCl}_{2}$, $40 \mathrm{~mm}$ of dNTP, $0.1 \mathrm{M}$ of each primer and 0.5 unit of Taq DNA polymerase. The cycle parameters consisted of 35 cycles of denaturation $\left(95^{\circ} \mathrm{C}\right.$ at $\left.30 \mathrm{~s}\right)$, annealing $\left(47.3^{\circ} \mathrm{C}\right.$ at $\left.30 \mathrm{~s}\right)$ and extension $\left(72^{\circ} \mathrm{C}\right.$ at $\left.60 \mathrm{~s}\right)$. The annealing temperature was determined through optimization. The amplified products were visualized on $1 \%$ agarose gels, run for approximately $75 \mathrm{~V}$ for 60 min.

The PCR products were then purified using Wizard $\circledast$ SV Gel and PCR Clean-Up system by Promega according to the manufacturer's protocol and then sequenced bi-directionally by First Base Laboratories Sdn Bhd, Malaysia using forward primers, which were used earlier for PCR amplifications. Sequencing was done using BigDye ${ }^{\circledR}$ Terminator v3.0 Cycle sequencing kit (ACGT) on a $\mathrm{ABI} 377$ automated sequencer (PE Applied Biosystem).

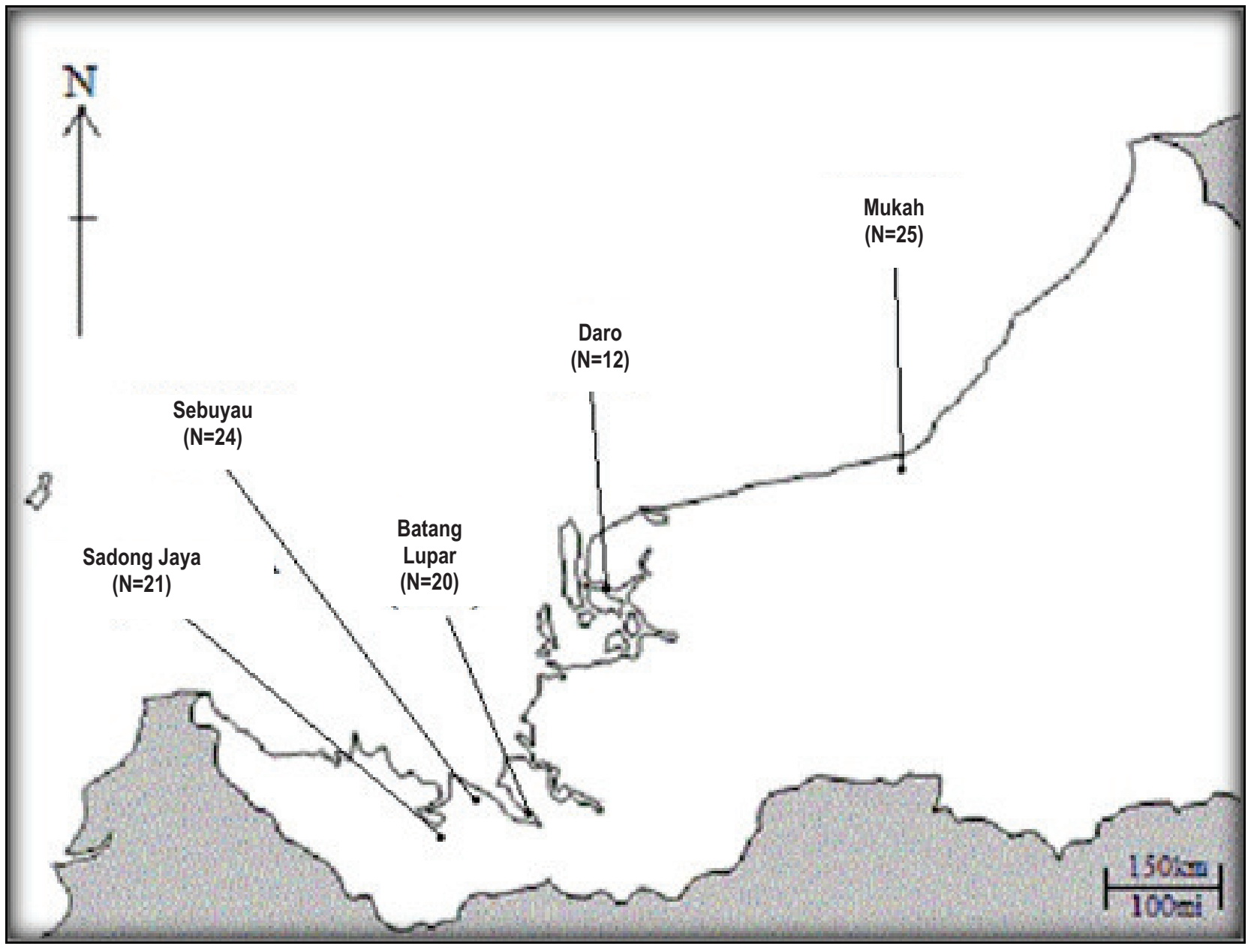

Fig. 1: Map indicating sampling location of Tenualosa toli in specific locations in Sarawak, Malaysia 
Data analysis : DNA sequencing results were viewed in the Chromas Lite (version 2.1.1 copyright(C) 1998-2013) software (Technelysium Pty Ltd), http://www.technelysium.com.au. The multiple sequence alignment were done using CLUSTALX version 2.1 (Larkin et al. 2007). Haplotypes were detected using FaBox (1.41) an online fasta sequence toolbox and the sequences were then deposited into Genbank to obtain the accession number. The accession number of all the haplotypes deployed in this study is shown in Table 1.

Analyzation of the Cyt $b$ sequences were conducted using MEGA version 7.0.18 (Tamura et al. 2013). The pairwise genetic distance between each haplotype were calculated using Kimura two-parameter evolution model (Kimura, 1980) implemented in MEGAversion 7.0.18.

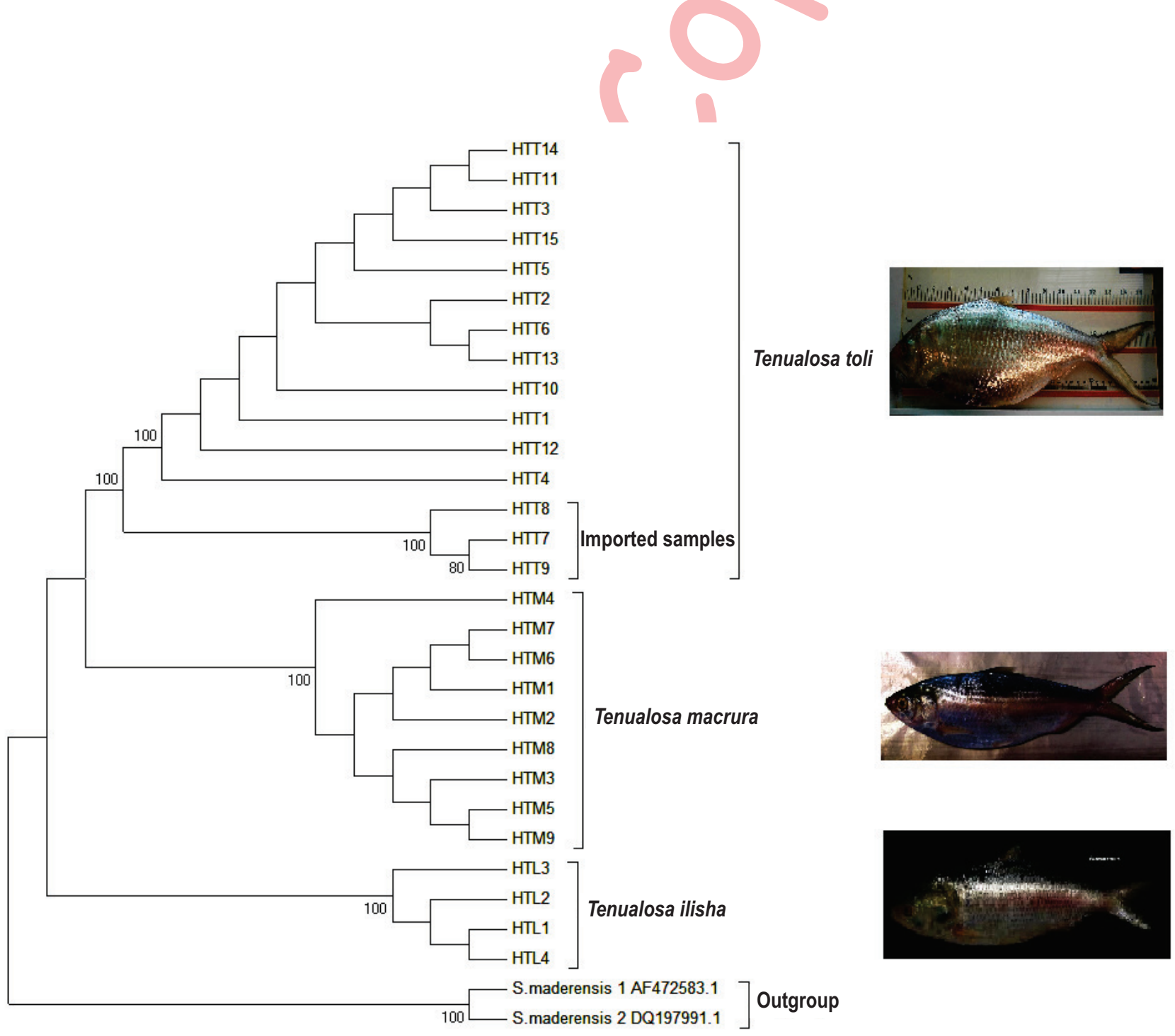

Fig. 2 : Phylogenetic relationships among Tenualosa toli, Tenualosa macrura, Tenualosa ilisha and outgroup (Sardinella maderensis) haplotypes utilized in the present study. The bootstrap percentage values presented at each nodes corresponds to the Neighbour-Joining/Maximum Likelihood $(\mathrm{NJ} / \mathrm{ML})$ analyses
Phylogenetic relationships were inferred using three different methods of analysis: neighbour-joining (NJ) (Saitou and Nei, 1987), maximum parsimony (MP) and maximum likelihood (ML). A distance analysis using the NJ method was done using a close neighbor-interchange (CNI) option implemented in MEGA version 7.0.18. (Tamura et al., 2013). The NJ clustering was performed using the Kimura two-parameter evolutionary model (Kimura, 1980). Phylogenetic confidence were estimated by bootstrapping (Felsenstein, 1985) with 1000 replicate data sets. The model with the best maximum likelihood (ML) score using Tamura Nei (TN93+I) were used to construct ML tree (Tamura and Nei, 1993). Bootstrap tree were computed using 1000 replicate data sets. All phylogenetic tree were rooted with an outgroup from the genus Sardinella which was Sardinella maderensis. 
Table 1: List of haplotypes with corresponding species name and Genbank Accession number (Abbreviation: TT= Tenualosa toli, TM= Tenualosa macrura, $\mathrm{TL}=$ Tenualosa ilisha)

\begin{tabular}{|c|c|c|c|c|c|}
\hline Haplotype & Species name & Collected from & Number of samples & Genbank Number & Accession \\
\hline \multirow[t]{5}{*}{ HTT1 } & \multirow[t]{5}{*}{ T. toli } & Sebuyau & 12 & \multirow[t]{5}{*}{ Kt630278 } & \\
\hline & & Sadong Jaya & 12 & & \\
\hline & & Batang Lupar & 11 & & \\
\hline & & Daro & 7 & & \\
\hline & & Mukah & 13 & & \\
\hline HTT2 & T. toli & Sebuyau & 2 & Kr261091 & \\
\hline \multirow[t]{5}{*}{ HTT3 } & \multirow[t]{5}{*}{ T. toli } & Sebuyau & 8 & \multirow[t]{5}{*}{ KR261092 } & \\
\hline & & Sadong Jaya & 8 & & \\
\hline & & Batang Lupar & 7 & & \\
\hline & & Daro & 4 & & \\
\hline & & Mukah & 9 & & \\
\hline HTT4 & T. toli & Sebuyau & 1 & Kx859096 & \\
\hline HTT5 & T. toli & Sebuyau & 1 & Kr261093 & \\
\hline HTT6 & T. toli & Sebuyau & 1 & Kx859097 & \\
\hline HTT7 & T. toli & Satok market & 7 & Kr827625 & \\
\hline HTT8 & T. toli & Satok market & 1 & Kr827626 & \\
\hline HTT9 & T. toli & Satok market & 1 & Kx859098 & \\
\hline HTT10 & T. toli & Daro & 1 & Ku888655 & \\
\hline HTT11 & T. toli & Mukah & 1 & Kx859099 & \\
\hline HTT12 & T. toli & Mukah & 1 & Kx859100 & \\
\hline HTT13 & T. toli & Mukah & 1 & Kx859101 & \\
\hline HTT14 & T. toli & Batang Lupar & 1 & Kx859102 & \\
\hline HTT15 & T. toli & Batang Lupar & 1 & Kx859103 & \\
\hline HTM1 & T. macrura & Sadong Jaya & 1 & Kr261094 & \\
\hline \multirow[t]{4}{*}{ HTM2 } & \multirow[t]{4}{*}{ T. macrura } & Sadong Jaya & 4 & \multirow[t]{4}{*}{ KT630282 } & \\
\hline & & Samarahan & 0 & & \\
\hline & & Daro & 1 & & \\
\hline & & Sibu & 3 & & \\
\hline HTM3 & T. macrura & Sadong Jaya & 1 & Kr261095 & \\
\hline HTM4 & T. macrura & Sadong Jaya & 1 & Kx084540 & \\
\hline HTM5 & T. macrura & Samarahan & 1 & Kx859104 & \\
\hline HTM6 & T. macrura & Samarahan & 1 & Kx859105 & \\
\hline HTM7 & T. macrura & Samarahan & 1 & Kt630283 & \\
\hline HTM8 & T. macrura & Sibu & 1 & Kx859106 & \\
\hline HTM9 & T. macrura & Sibu & 1 & Kx859107 & \\
\hline HTL1 & T. ilisha & Bangladesh & 1 & Kx859108 & \\
\hline HTL2 & T. ilisha & Bangladesh & 1 & Ku888657 & \\
\hline HTL3 & T. ilisha & Bangladesh & 1 & Ku888658 & \\
\hline HTL4 & T. ilisha & Bangladesh & 1 & KX859109 & \\
\hline
\end{tabular}

In order to obtain the genetic structure, hierarchical analysis of molecular variance (AMOVA) as well as pairwise Fst values of different population of $T$. toli, Arlequin version 3.5.5 (Excoffier and Lischer, 2010) was utilized in this study. Demographic history were estimated based on two different approaches mainly Tajima's D (Tajima, 1989) and Fu's FS (Fu, 1997 where the values were obtained through neutrality test conducted in Arlequin version 3.5.5. This value signifies population expansion. Mismatch distribution which is mainly frequency distribution of pairwise differences between sequences were also conducted through this software. This analysis produces three values, mainly $\theta 0$ (before population growth), $\theta 1$ (after population growth) and $T$ (time since expansion time expressed in units of mutational time) (Rogers and Harpending, 1992). Associated graph for this analysis were obtained through Dnasp version 5.0.1 (Librado and Rozas, 2009). This software was also utilized for DNA polymorphism analysis in order to obtain nucleotide and haplotype diversity. PopArt version 1.7 (Bandelt et al., 1999) was used to obtain minimum spanning network.

\section{Results and Discussion}

A total of 139 samples, each comprising of a Cyt b sequence length of $910 \mathrm{bp}$, were used in the present study and a 
Table 2: Numbers of Tenualosa toli haplotypes with corresponding locality and relative frequency

\begin{tabular}{|c|c|c|c|c|c|c|}
\hline Haplotype & $\begin{array}{l}\text { Sebuyau } \\
(\mathrm{SB}) \\
(\mathrm{N}=24) \\
\end{array}$ & $\begin{array}{l}\text { Sadong Jaya } \\
(\mathrm{SJ}) \\
(\mathrm{N}=21) \\
\end{array}$ & $\begin{array}{l}\text { Daro } \\
(\mathrm{D}) \\
(\mathrm{N}=12) \\
\end{array}$ & $\begin{array}{l}\text { Mukah } \\
(\mathrm{M}) \\
(\mathrm{N}=25) \\
\end{array}$ & $\begin{array}{l}\text { Batang } \\
\text { Lupar (BL) } \\
(\mathrm{N}=20)\end{array}$ & $\begin{array}{l}\text { Imported } \\
\text { samples } \\
\text { (IS) (N=9) }\end{array}$ \\
\hline HTT1 & 0.500 & 0.571 & 0.583 & 0.520 & 0.550 & \\
\hline HTT2 & 0.083 & & & & & \\
\hline HTT3 & 0.333 & 0.381 & 0.333 & 0.360 & 0.350 & \\
\hline HTT4 & 0.042 & & & & & \\
\hline HTT5 & 0.042 & & & & & \\
\hline HTT6 & & 0.048 & & & & \\
\hline HTT7 & & & & & & 0.778 \\
\hline HTT8 & & & & & & 0.111 \\
\hline HTT9 & & & & & & 0.111 \\
\hline HTT10 & & & 0.083 & & & \\
\hline HTT11 & & & & 0.040 & & \\
\hline HTT12 & & & & 0.040 & & \\
\hline HTT13 & & & & 0.040 & & \\
\hline HTT14 & & & & & 0.050 & \\
\hline HTT15 & & & & & 0.050 & \\
\hline $\begin{array}{l}\text { Nucleotide } \\
\text { diversity } \\
\text { (PiJC) }\end{array}$ & 0.001 & 0.001 & 0.001 & 0.001 & 0.001 & 0.000 \\
\hline $\begin{array}{l}\text { Number of } \\
\text { haplotypes }\end{array}$ & 5 & 3 & 3 & 5 & 4 & 3 \\
\hline $\begin{array}{l}\text { Haplotype } \\
\text { diversity (Hd) }\end{array}$ & 0.656 & 0.552 & & 0.620 & 0.600 & 0.417 \\
\hline $\begin{array}{l}\text { Number of } \\
\text { polymorphic } \\
\text { sites }\end{array}$ & 4 & 2 & & 7 & 3 & 2 \\
\hline
\end{tabular}

$\mathrm{TT}=$ Tenualosa toli

total of 28 different haplotypes were identified. The extracted samples yielded $15 \mathrm{~T}$. toli haplotypes (HTT1-HTT15), $9 \mathrm{~T}$. macrura haplotypes (HTM1-HTM9) and 4 T. ilisha haplotypes (HTL1-HTL4). The lists of haplotypes used in this study are presented in Table 1. Overall, 709 bp (77.9\%) were conserved sites, 201 bp (22.1\%) were variable sites and 184 bp (20.2\%) were parsimony informative sites from the total of $910 \mathrm{bp}$ of the Cyt b gene fragment. All haplotypes were deposited in Genbank with accession number as listed in Table 1.The percentage of the average total nucleotide composition from the sequenced samples were $A=24.0 \%, T=28.3 \%, C=30.7 \%, G=16.9 \%$.

For phylogenetic analyses, Neighbour Joining (NJ) and Maximum Likelihood ( $\mathrm{ML}$ ) phylogram produced similar tree topologies. However, the positioning of $T$. ilisha was different for the MP phylogram as in Fig. 2, which divides samples into two major clusters. The first cluster grouped all the T. toli samples and T. macrura samples with a high bootstrap supports value while another cluster was composed of $T$. ilisha sequences. This is because data handling in all analysis are different. In NJ and ML, data handling is done in an easy manner as the information of multiple alignment of sequences is reduced to a more simple form. In this process, however, some of the information will be lost, especially regarding identities of ancestral and derived nucleotides at each position when multiple alignments is conducted (Brown, 2002). MP on the other hand assumes that evolution follows the shortest possible route and that the correct tree is the one that requires fewer nucleotide changes to produce observed differences between sequences (Brown, 2002). MP and ML map the history of gene sequences compared to NJ which uses distance based methods (Holder and Lewis, 2003).

All sequences were grouped together according to their taxonomic identification based on their morphological characteristics. In the NJ and ML phylogram tree, T. toli samples were grouped into two clusters. The first cluster consisted of all haplotype except for HTT7, HTT8 and HTT9, where these haplotypes were separated from the main clade and or could be genetically divided. This indicates that these haplotypes are comprised of distinctive individuals belonging to the same species. The first clade consists of sequences obtained from Sebuyau, Sadong Jaya, Batang Lupar, Daro and Mukah, which showed high genetic similarities to each other. HTT7, HTT8 and HTT9 are unique haplotypes that consist of samples obtained from Satok market. 
Among the $15 T$. toli haplotypes, which represents 6 different populations, 2 had shared haplotypes whereas 13 were unique haplotypes (Table 2). The 111 partial Cyt b sequences of $T$. toli consisted of $39(4.2 \%)$ variable sites, $871(95.7 \%)$ conserved sites and $28(3.1 \%)$ parsimony informative sites out of $910 \mathrm{bp}$. The protein translation of $910 \mathrm{bp}$ fragment of all sequences produced 27 haplotypes based on 303 amino acid residues and these residues showed $52.8 \%$ variable sites. HTT1 and HTT3 are common haplotype, which were found in all the selected populations in Sarawak. T. toli samples from Sebuyau and Mukah produced 3 unique haplotypes, whereas Batang Lupar produced 2 unique haplotypes. Sadong Jaya and Daro each produced 2 unique haplotypes. Both Sebuyau and Mukah produced 5 haplotypes, which was the highest number of haplotypes produced in one particular population.

The utilization of mtDNA in this study managed to provide insight into the genetic makeup of $T$. toli collected from various localities in Sarawak. Phylogenetic analysis of partial Cyt b fragment supported the reciprocally monophyletic relationship between the three Tenualosa species. The high genetic divergences found between species (>13\%K2P) further showed their genetic distinctiveness. Genetic distance values greater than $11 \%$ indicate specific species recognition (Baker and Bradley, 2001). The present mtDNA data suggests that $T$. toli and $T$. macrura differed genetically as high genetic divergence between the indigenous T. toli and T. macrura (13.9\%-15.3\%) found in this study supported their taxonomic status as distinct species. It is difficult to morphologically distinguish these species, especially during their juvenile stage (Blaber, 2009), which further supports the advantage of molecular markers over morphological characterization for species identification.

In this study, DNA polymorphism analysis of $T$. toli across 6 different populations mainly Sebuyau, Sadong Jaya, Batang Lupar, Daro, Mukah and imported samples were conducted. The nucleotide diversity in all population was low (0.001), whereas haplotype diversity ranged from 0.417 (Imported samples) to 0.656 (Sebuyau) (Table 2). The highest number of polymorphic site (7 sites) was found in haplotypes from Mukah. On the other hand, highest haplotye diversity were found in haplotypes from Sebuyau as it contained the highest number of haplotypes,

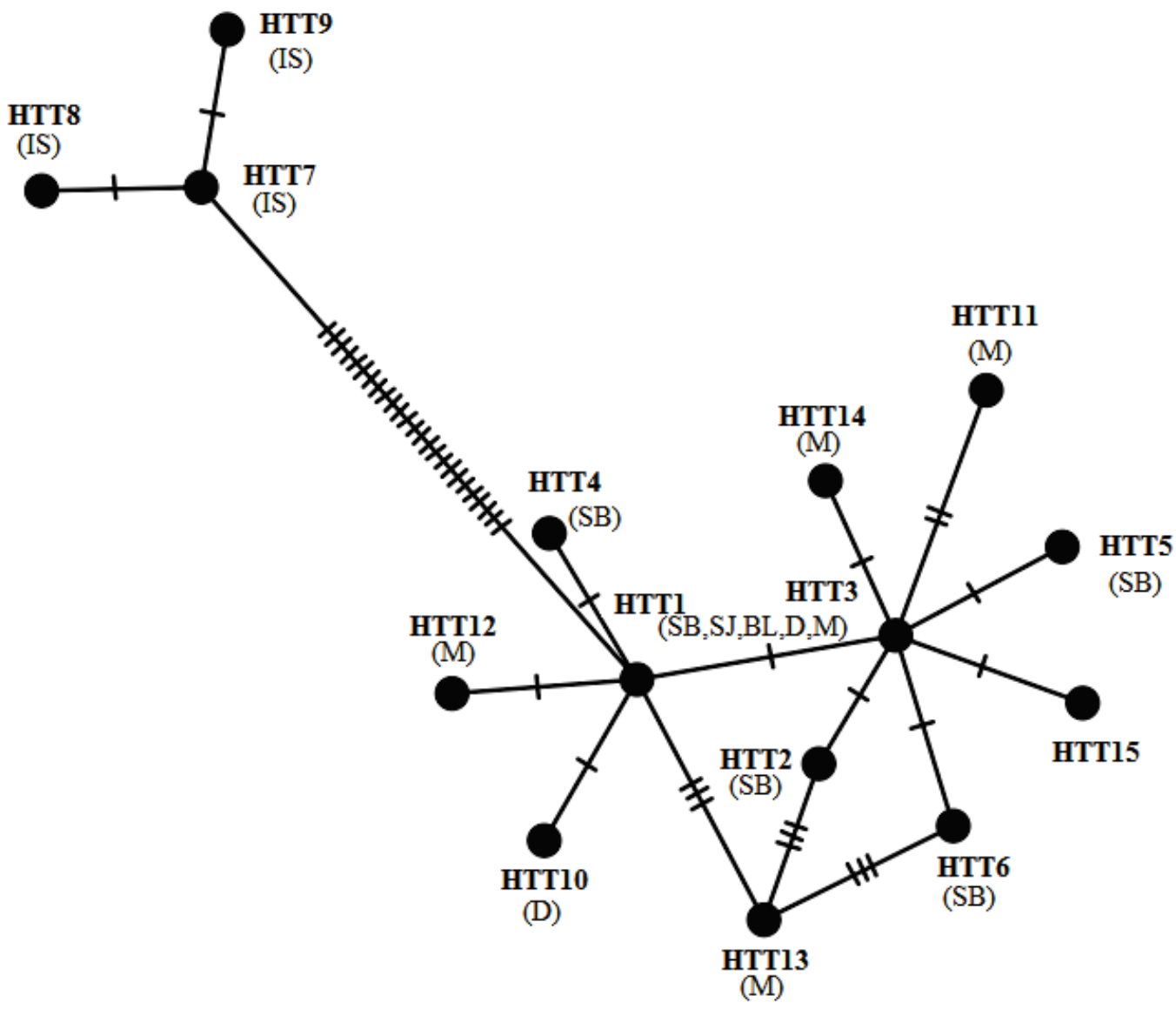

Fig. 3 : Minimum spanning network showing relationships among 15 mitochondrial DNA Cyt b haplotypes of Tenualosa toli with their respective population. The hatch marks among the haplotypes show single mutational steps 

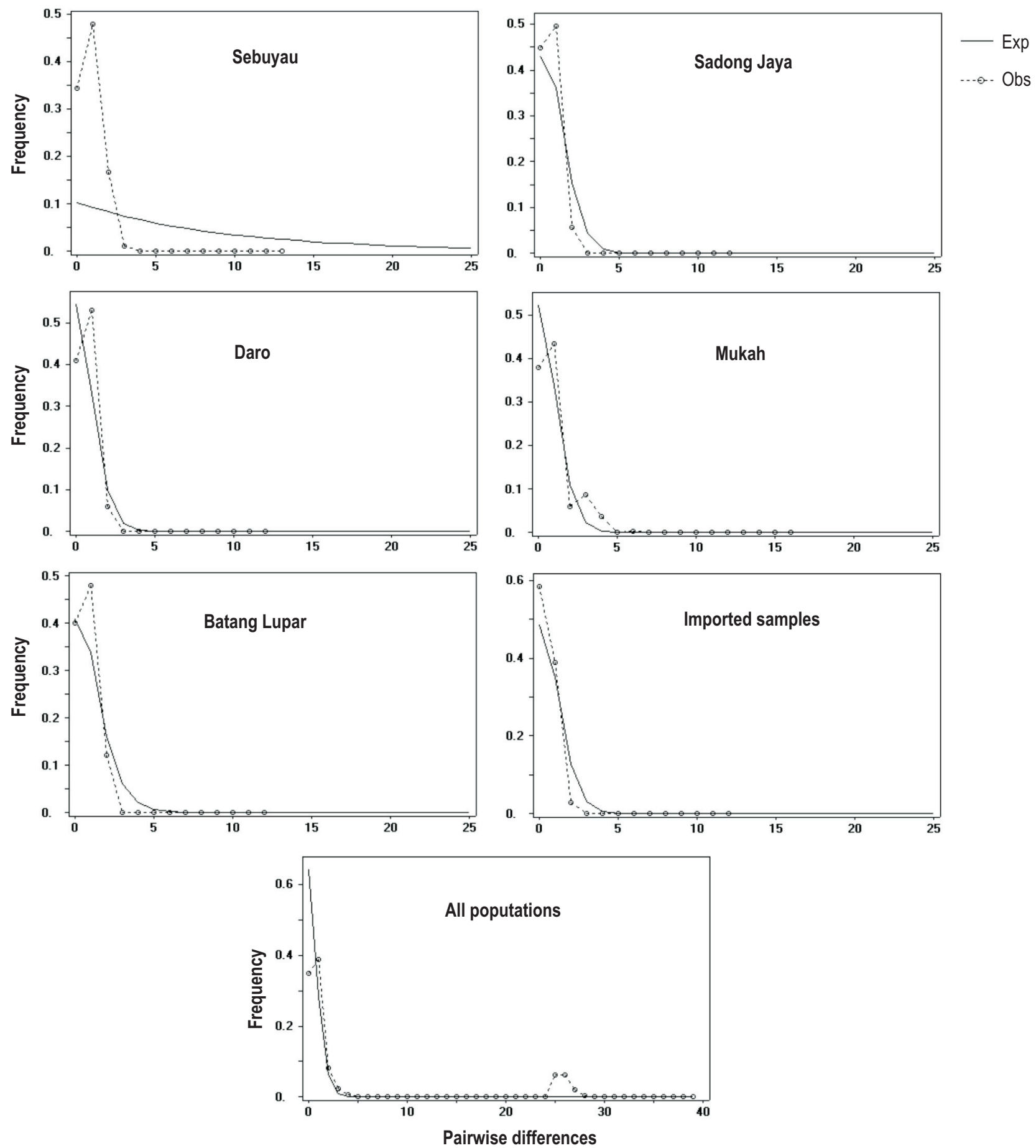

Fig. 4: Observed and expected mismatch distribution for expanding population of Tenualosa toli for different and whole population 
Table 3: Below the diagonal: pairwise Tamura-Nei genetic distances among 6 populations of Tenualosa toli. Above the diagonal: population subdivision (Fst) values

\begin{tabular}{lllllll}
\hline & Sebuyau & Sadong Jaya & Daro & Mukah & Batang Lupar & Imported samples \\
\hline Sebuyau & & $0.000^{*}$ & $0.000^{*}$ & $0.000^{*}$ & $0.000^{*}$ & $0.971^{* * *}$ \\
Sadong Jaya & 0.001 & & $0.000^{*}$ & $0.000^{* * *}$ & $0.000^{* *}$ & $0.978^{* * *}$ \\
Daro & 0.001 & 0.001 & & $0.000^{*}$ & $0.000^{*}$ & $0.978^{* * *}$ \\
Mukah & 0.001 & 0.001 & 0.001 & & $0.000^{*}$ & $0.967^{* * *}$ \\
Batang Lupar & 0.001 & 0.001 & 0.001 & 0.001 & & $0.975^{* * *}$ \\
Imported samples & 0.030 & 0.029 & 0.029 & 0.030 & 0.029 & \\
\hline
\end{tabular}

Upper diagonal population subdivision (Fst) values and probability test (Chi-square) for population differentiation based on 1000 permutations of the sequence data, significance levels $\left(p<0.05=^{*}, p<0.01=^{* *}, p<0.001={ }^{* * *}\right)$

Table 4: Neutrality test (Tajima's D and Fu' FS) estimates (signifance level: $p<0.01$ ) for selected populations of Tenualosa toli from Sarawak

\begin{tabular}{|c|c|c|c|c|c|c|c|}
\hline Population & $\begin{array}{l}\text { Tajima's D test } \\
\text { Pi }\end{array}$ & Tajima's D & p-value & $\theta \mathrm{pi}$ & $\begin{array}{l}\text { Fu's FS test } \\
\text { Exp no of alleles }\end{array}$ & FS & $\mathrm{p}$-value \\
\hline Sebuyau & 0.844 & -0.579 & 0.316 & 0.844 & 3.427 & -1.326 & 0.127 \\
\hline Sadong Jaya & 0.610 & 0.222 & 0.650 & 0.610 & 2.777 & 0.204 & 0.5000 \\
\hline Batang Lupar & 0.721 & 0.393 & 0.373 & 0.721 & 3.001 & 0.748 & 0.268 \\
\hline Daro & 0.652 & -0.0475 & 0.428 & 0.652 & 2.517 & -0.137 & 0.321 \\
\hline Mukah & 0.980 & -1.458 & 0.065 & 0.980 & 3.772 & -0.890 & 0.270 \\
\hline Imported & 0.444 & -1.362 & 0.090 & 0.444 & 1.981 & -1.081 & 0.048 \\
\hline
\end{tabular}

whereas the lowest value was from haplotypes found in imported samples.

Haplotypes containing imported samples showed slightly higher genetic differences from all the other $T$. toli haplotypes (2.9\%-3.3\%), even though they belonged same species. This is based on the BLAST result showing that this haplotype is $99 \%$ identical to $T$ toli sequences found in Genbank. As for the genetic distance between $2 \%$ to $11 \%$, this could indicate conspecific populations (Baker and Bradley, 2001). According to the traders in the Satok market, these fish were imported from India, which would support the high genetic difference between imported and local samples. HTT7, HTT8 and HTT9 belong to a different gene pool or breeding group as unique haplotype portrays populations that belong to a geographically isolated population, but there were possible events of interbreeding leading to gene flow and low genetic differentiation (Nandeibam et al., 2013). The difference between Sarawak and imported samples could be explained by several factors such as small population sizes, past bottleneck events or limited migration due to existence of physical barriers (Nguyen et al., 2006). This raises a question as to the origin of $T$. toil. which could be resolved by collecting more imported T. toli samples from markets. Southeast Asia is believed to be mostly on the Eurasian plate and this area is actually surrounded in close proximity to the Indian-Australian, as well as Pacific and Philippine plates (Carpenter, 1998). This portrays the biggest concentration of plates in a continuous marine system leading to an assumption that all the surrounding plates disperse different species into Southeast Asian Sea leading to a huge species diversity (Carpenter, 1998). This could be one assumption as to why imported and local $T$. toli samples are genetically diverged even though they belong to the same species.

High genetic similarities and sharing of common haplotypes between $T$. toli samples from selected populations in Sarawak indicate a high level of gene flow and sharing of genetic material. This can be justified by their life history pattern as anadromous species living most of their life (especially mature stage) in estuaries, but spawn in rivers during breeding season (Whitehead, 1985). T. toli could be found in estuarine waters and feed along shoreline waters where their migration pattern ranges from Sematan to Lawas entering Lupar and Lassa rivers for spawning (Awang Alim et al., 2012). Thus, it is predicted that migration behavior of $T$. toli during spawning season, between groups from different population might have resulted in the homogeneity of mtDNA haplotypes between them. The number of differences between two sequences increases as the time since this sequence diverged from their last common ancestor increases and measures of genetic differences between sequences is not reliable to indicate when they diverged because the rate of sequence evolution is not constant over time (Holder and Lewis, 2003).

High genetic differences and higher Fst values (0.9670.979) between $T$. toli samples from Sarawak and imported 
Table 5 : Mismatch distribution parameter estimates for selected populations of Tenualosa tolifrom Sarawak

\begin{tabular}{llll}
\hline & & \multicolumn{2}{c}{ Mismatch distribution } \\
Population & $\mathrm{T}(95 \% \mathrm{Cl})$ & $\boldsymbol{\theta 0}$ & $\boldsymbol{\theta 1}$ \\
\hline Sebuyau & 2.482 & 0.000 & 3407.19 \\
Sadong Jaya & 2.115 & 0.056 & 3414.7 \\
Batang Lupar & 0.949 & 0.028 & 3427.2 \\
Daro & 0.000 & 0.113 & 6827.18 \\
Mukah & 1.824 & 0.028 & 3417.2 \\
Imported & 0.000 & 0.056 & 6822.18 \\
\hline
\end{tabular}

samples could imply the absence of any recent migration or gene flow between these populations. This is further supported by the number of fixed haplotypes among imported samples. Within the populations in Sarawak, low mtDNA variations were observed among all the $T$. toli samples. High number of haplotypes (3-5), high haplotype diversity (0.552-0.656) and high polymorphic loci (2-7) but lack of significant differences in pairwise Fst values among population in Sarawak supports high level of intrapopulation variation compared to interpopulation variation. This result is similar to the study on T. tambroides (Nguyen et al. 2006). Low level of mtDNA variations could be due to availability of haplotype HTT1 and HTT2 in almost all of the populations. High haplotype and low nucleotide diversity might be an indicator of overfishing as all of these 5 populations are among the core terubok areas in Sarawak.

Haplotype diversity and nucleotide diversity value for Daro and Mukah observed in this study were different compared to the one observed in the study by Abdul Aziz (2015). Haplotype diversity in this study was higher for both Daro and Mukah whereas the nucleotide diversity for Daro was lower compared to the previous study. As for Tajima's D value, Sebuyau, Daro and Mukah population portrayed a negative value. A negative $D$ value could be the result of recently occurred bottleneck leading to population size expansion (Tajima, 1989). Negative Tajima's D value implies excess of low frequency polymorphism which could be due to population size expansion. On the other hand, positive value could be due to population size reduction and balancing selection (Tajima, 1989). This could be seen in Sadong Jaya and Batang Lupar population. As for Fu's Fs-Statistical tests which were done for demographic history, a negative value is expected from a recent population expansion whereas a positive value is from a recent population bottleneck. This shows that recent population expansion occurred in Sebuyau and Batang Lupar.

The minimum spanning network (MSN) of 15 haplotypes of $T$. toli (Fig. 3) obtained from selected locality in Sarawak and imported samples showed high haplotype variability among samples collected in Sarawak. Haplotypes consisting of imported samples are clustered together. Most of the sequences are connected by at least one mutational step leading to the fact that there are no geographically based defined clades for $T$. toli population in Sarawak. Most of the sequences are mixed, hence leading to the existence of mixed haplotypes. MSN phylogram could not portray well defined separation of $T$. toli samples based on their geographical clades.

Pairwise Fst values for genetic differentiation among populations showed significant levels of genetic differentiation in all comparisons between imported $T$. toli population and local samples. However, there were no genetic differentiations in pairwise Fst values in most comparisons among populations from Sarawak (Table 3). Pairwise genetic distances calculated using Tamura-Nei model among $T$. toli populations in this study are shown in Table 3. The highest genetic distances were observed between imported and local samples (2.9\%). There were minimum genetic similarities among samples from Sarawak and imported samples. On the other hand, low genetic distances were observed among all the locally collected samples $(0.1 \%)$.

AMOVA results revealed that the majority of variance as well as percentage of variation were among populations. Interpopulation variation showed a higher value, which about $86 \%$ is compared to within population variation with only about $14 \%$ variation. Mismatch distribution for expanding populations of $T$. toli portrayed a multimodal pattern (Fig. 4). Tajima's D value was negative for Sebuyau, Daro, Mukah and Imported samples. On the other hand, Fu's FS also showed negative value for Sebuyau, Daro, Mukah and imported samples (Table 4) but both analysis were not significant. Mismatch distribution value consists of $\theta 0$ and $\theta 1$ value which signifies growth rate of $T$. toli populations (Table 5).

The Tau and $\theta$ value for mismatch distribution in this study show similar pattern to $L$. maculatus, which portrayed large-scale expansion (Liue et al., 2006) and in accordance to neutrality tests. Sebuyau, Daro and Mukah portrayed negative Tajima's D value and Fu's FS value. Population expansion theory supported by unimodal pattern in mismatch distribution analysis, negative Tajima's D and Fu's FS value, high level of haplotype diversity and low level of nucletiode diversity (Chen et al., 2004).

The significance of this study on conservation could be the idea of selecting stocks for breeding program as it is believed that population, which portrays high intrapopulation variation could be used as base-line stocks for selective breeding (Nguyen et al., 2006). This preliminary investigation has managed to provide a better insight on the phylogeny, genetic identity and level of genetic differences between the three shads. High genetic divergences and monophyletic status between T. toli, T. macrura and $T$. ilisha confirmed their taxonomic status as distinct species thus proves that Cyt $b$ is a suitable gene for the purpose of species, identification. The rapid decline of local terubok population necessitates immediate study to quantify the remaining level of genetic variation in $T$. toli and $T$. macrura to assist in conservation and management of terubok in Sarawak. 
So, it is recommended that more individuals of genus Tenualosa from different population should be included to provide a better insight to determine the phylogenetic relationship, as this study only focuses on few localities in Sarawak. Utilization of different types of genetic marker is recommended to obtain a more robust findings on the population of $T$. toli.

\section{Acknowledgments}

The authors would like to thank all the staff from Department of Aquaculture and lab mates from Fish Genetics and Breeding laboratory, who have assisted me in this project. The authors would also like to take this opportunity to thank Universiti Putra Malaysia for giving me an opportunity to conduct my research. This project was funded by Fundmental Research Grant Scheme FRGS/1/2014/STWN04/UPM/02/3.

\section{References}

Abdul Aziz, H.A., Z. Tarmizi, N.M. Ali, N.A. Ariffin, M.D.D. Abdullah, W.L. Lian, S.Y. Giat, T.N.A.M. Jaafar, A.M.A. Bolong, A.A.A. Kasim and S.M. Sheriff: Mitochondrial DNA Diversity of Terubok (Tenualosa toli) from Daro and Mukah, Sarawak Inferred by Partial Cytochrome b (Cyt b). J. FishAquat. Sci., 10, 92-101 (2015)

Arai, T. and R. Amalina: New record of a tropical shad Tenualosa ilisha (Teleostei: Clupeidae) in Malaysian waters. Mar. Biodivers. Rec., 7, 1-4 (2014).

Avise, J.C.: Molecular markers, natural history and evolution. New York: London: Chapman and Hall (1994).

Avise, J.C.: Phylogeography: The history and formation of species: Harvard University Press, Cambridge, M.A. (2000).

Awang Kasim, A.A., P. Wong and Khairulniezawaymie. The terubok (Tenualosa spp.) rehabilitation integrated program (TRIP) and conservation in Sarawak. In: Proceedings of UMT $11^{\text {th }}$ International Annual Symposium on Sustainability Science and Management, Universiti Malaysia Terengganu, pp. 1476-1479 (2012).

Baker, R. J. and R.D. Bradley: A test of the genetic species concept: Cytochrome $b$ sequences and mammals. J. Mammal., 82, 960973 (2001).

Baker, R.J. and R.D. Bradley: Speciation in mammals and the Genetic Species Concept. J. Mammal., 87, 643-662 (2006).

Bandelt, H.J., P. Forster and A. Rohl: Median-joining networks for inferring interspecific phylogenies. Mol. Biol. Evol., 16, 37-48 (1999).

Barat, A., S. Ali, J. Sati and G.K. Sivaraman: Phylogenetic analysis of fishes of the subfamily Schizothoracinae (Teleostei: Cyprinidae) from Indian Himalayas using Cytochrome $b$ gene. Indian J. Fish., 59, 43-47 (2012).

Blaber, S.J.M.: Can the ecosystem approach improve management of tropical estuarine fisheries for diadromous species. Am. Fish. Soc. Symp., 69, 649-661 (2009).

Blaber, S.J.M., D.T. Brewer, D.A. Milton, G.S. Merta, D. Efizon, G. Fry and T. Van der Velde: The life history of the protandrous tropical shad Tenualosa macrura (Alosinae: Clupeidae): Fishery Implications. Estuar. Coast. Shelf Sci., 49, 689-701 (1999).

Blaber, S.J.M., D.A. Milton, J. Pang, P. Wong, O. Boon-Teck, L. Nyigo and D. Lubim: The life history of the tropical shad Tenualosa toli from Sarawak: First evidence of protandry in the Clupeiformes.
Environ. Biol. Fish., 46, 225-242(1996).

Blaber, S.J.M., G. Fry, D. Milton, T. Van der Velde, O. Boon-Teck, J. Pang and P. Wong: The life history of Tenualosa macrura in Sarawak, further notes on protandry in the genus and management strategies. Fish. Manag. Ecol., 12, 201-210 (2005).

Brown, T.A.: Genomes. $2^{\text {nd }}$ Edn., Oxford Wiley-Liss (2002).

Carpenter, K.E.: An introduction to the oceanography, geology, biogeography and fisheries of the tropical and subtropical waters and central Pacific. FAO species identification guide for fishery purpose: The living marine resources of the western central Pacific Rome: FAO, pp. 1-9 (1998).

Chen, C.A., M.C.A. Ablan, J.W. McManus, J.D. Bell, V.S. Tuan, A.S. Cabanban and K.T. Shao: Population and genetic variability of six wrasse (Thallasoma hardwicki) in Northern South China Sea revealed by mitochondrial region sequences. Marine Biotechnology, 6, 312-326 (2004).

Cook, B. D., M. Baker, T.J. Page, S.C. Grant, J.H. Fawcett, D.A. Hurwood and J.M. Hughes: Biogeographic history of an Australian freshwater shrimp, Paratya australiensis (Atydae): The role of life history in phylogeographic diversification. Mol. Ecol., 15, 1083$1093(2006)$.

Esa, Y.B., J.M. Waters and G.P. Wallis: Introgressive hybridization between Galaxias 262 depressiceps and Galaxias sp D (Teleostei: Galaxiidae) in Otago, New Zealand: Secondary contact mediated by water races. Conserv. Genet., 1, 329-339 (2000).

Esa, Y.B., S.S. Siraj, S.K. Dud, J.R.R. Japning, A.R., Khairul Adha and S.G. Tan: Molecular systematics of mahseers (Cyprinidae) in Malaysia inferred from sequencing of a mitochondrial Cytochrome c oxidase I (COI) gene. Pertanika J. Trop. Agric. Sci., 31, 263-269 (2008).

Esa, Y.B., R.R.J. Jeffrine, A.R. Khairul Adha, S.S. Siraj, S.K. Daud, S.G. Tan and S. Sungan: Phylogenetic relationship among several freshwater fishes (Family: Cyprinidae) in Malaysia inferred from partial sequencing of the Cytochrome $b$ mitochondrial DNA (mtDNA) gene. Pertanika J. Trop. Agri. Sci., 35, 307-318 (2012).

Esa, Y.B. and A.R. Khairul Adha: Genetic structure and preliminary findings of cryptic diversity of the Malaysian Mahseer (Tor tambroides Valenciennes: Cyprinidae) inferred from mitochondrial DNA and microsatellite analyses. BioMed Res. Int., 2013, 1-14 (2013).

Excoffier, L. and H.E.L. Lischer: Arlequin suite ver 3.5: A new series of programs to perform population and genetics analyses under Linux and Windows. Mol. Ecol. Resour., 10, 564-567 (2010).

Felsenstein, J.: Confidence limits on phylogenies: An approach using the bootstrap. Evolution, 39, 783-791 (1985).

Fu, Y. X.: Statistical tests of neutrality of mutations against population growth, hitchhiking and background selection. Genetics, 157, 915925 (1997).

Holder, M. and P.O. Lewis: Phylogeny estimation: Traditional and Bayesian approaches. Nat. Rev. Genet., 4, 275-284 (2003).

Hsieh, H.M., H.L. Chiang, L.C. Tsai, S.Y. Lai, N.E. Huang, A. Linacre and C.I.L. James: Cytochrome $b$ gene for species identification of the conservation animals. Forensic Sci. Int., 122, 7-18 (2001).

Irwin, D., T. Kocher and A. Wilson: Evolution of the Cytochrome $b$ gene of mammals. J. Mol. Evol., 32, 128-144 (1991).

Jeffrine, R.J.R. and Y.B. Esa: Phylogenetic analysis of Hampala fishes (Subfamily Cyprinina) in Malaysia inferred from partial mitochondrial Cytochrome b DNA sequences. Zool. Sci., 23, 893901 (2006). 
Kamarudin, K.R. and Y.B. Esa: Phylogeny and phylogeography of Barbonymus schwanenfeldii (Cyprinidae) from Malaysia inferred using partial Cytochrome $b$ mtDNA gene. J. Trop. Biol. Conser., 5, 1-13 (2009).

Khairul Adha, A.R., M. Hambali Tumiran, M.L. Shabdin, Y.B. Esa and A.A.S. Awang Husaini: The status of Tenualosa toli (Valenciennes, $1847)$ in the Southwest coast of Sarawak, Malaysia. Kuroshio Sci., 8, 39-44 (2014).

Kimura, M.: A simple method for estimating evolutionary rate of base substitutions through comparative studies of nucleotide sequences. J. Mol. Evol., 16, 111-120(1980).

Larkin, M.A., G. Blackshields, N.P. Brown, R. Chenna, P.A. McGettigan, H. McWilliam, F. Valentin, I.M. Wallace, A. Wilm, R. Lopez, J.D. Thompson, T.J. Gibson and D.G. Higgins: Clustal W and Clustal X version 2.0. Bioinformatics, 23, 2947-2948 (2007).

Librado, P. and J. Rozas: DnaSP v5: A software for comprehensive analysis of DNA polymorphism data. Bioinformatics, 25, 14511452 (2009).

Liu, J.X., T.X. Gao, K. Yokogawa and Y.P. Zhang: Differential population structuring and demographic history of two closely related fish species, Japanese sea bass (Lateolabrax japonicas) and spotted sea bass (Lateolabrax maculates) in Northwestern Pacific. Mol. Phylogenet. Evol., 39, 799-811 (2006).

Nandeibam, S.S., B.K. Behera and A.P. Sharma: Population structure of Puntius sophore inferred from variation in mitochondrial DNA sequences. Int. J. Res. Fish. Aquac., 3, 112-115(2013).

Nguyen, T.T., B. Ingram, S. Sungan, G. Gooley, S.Y. Sim, D. Tinggi and S.S. De Silva: Mitochondrial DNA diversity of broodstock of two indigenous mahseer species, Tor tambroides (Cyprinidae) cultured in Sarawak, Malaysia. Aquaculture, 253, 259-269 (2006).

Pääbo, S. and A.C. Wilson: Polymerase chain reaction reveals cloning artefacts. Nature, 334, 387-388(1988).

Rogers, A.R. and H. Harpending: Population growth curves in the distribution of pairwise genetic differences. Mol. Biol. Evol., 9, 552569 (1992).

Saitou, N. and T. Nei : The neighbor-joining method: A new method for reconstructing phylogenetic trees. Mol. Biol. Evol., 4, 406- 425 (1987).

Salini, J.P., D.A. Milton, M.J. Rahman and M.G. Hussain: Allozyme and morphological variation throughout the geographic range of the tropical shad, hilsa Tenualosa ilisha. Fish. Res., 66, 53-69 (2004).

Stepien, C.A. and T.D. Kocher: Molecules and morphology in studies of fish evolution. In: Molecular Systematic of Fishes(Eds.: T.D. Kocher and C.A. Stepien). London, Academic Press, pp. 1-11 (1997).

Tajima, F.: Statistical method for testing the neutral mutation hypothesis byDNApolymorphism. Genetics, 123, 585-595(1989).

Tamura, K. and M. Nei: Estimation of the number of nucleotide substitutions in the control region of mitochondrial DNA in humans and chimpanzees. Mol. Biol. Evol., 10, 512-536(1993).

Tamura, K., G. Stecher, D. Peterson, A. Fllipski and S. Kumar: MEGA6: Molecular evolutionary genetics analysis version 6.0. Mol. Biol. Evol., 30, 2725-2729 (2013).

Chauhan, T. and R. Kumar: Molecular marker and their applications in fisheries and aquaculture. Adv. Biosci. Biotechnol., 1, 281-291 (2010).

Whitehead, P.J.P.: FAO species catalogue Vol.70. Clupeoid fishes of the world (suborder Clupeoidei). An annotated and illustrated catalogue of the herrings, sardines, pilchards, sprats, shads, anchovies and wolf herrings. Part1- Chirocentridae, Clupeidae and Pristigasteridae, FAO Fisheries Synopsis, 125, 1-303 (1985). 